\title{
FENOMENA LESBIAN, GAY, BISEKSUAL DAN TRANSGENDER (SOLUSI DAN UPAYA PENCEGAHANNYA)
}

\author{
Yosi Aryanti \\ STIT Ablussunnah Bukittinggi, ochies1978@gmail.com
}

Diterima: 30 September $2019 \quad$ Direvisi : 2 Desember $2019 \quad$ Diterbitkan : 25 Desember 2019

\begin{abstract}
The phenomenon of lesbian, gay, bisexual and transgender (LGBT) in millennial times is no longer considered a new thing in society. Previously these behaviors were considered strange for some people, but in an age of increasingly sophisticated technology, this has become commonplace. Today many have openly stated and identified themselves as the identity of LGBT people or as supporters of their development. This large wave of groups striving to be recognized in the eyes of the world has been carried out intensively and continuously. Indonesia as the largest Muslim cannot be separated from the influence and threat of LGBT. This study aims to explore how the phenomenon of LGBT development and illustrate how solutions and efforts to prevent it. This research was compiled using a literature review approach related to LGBT studies. The results of the excavation found that the LGBT movement is no longer just an individual movement but has entered the public sphere. To overcome this condition, in addition to regulations relating to the movement of LGBT people, in the smallest environments in households must prepare methods and ways to prevent the presence of LGBT.
\end{abstract}

Keywords: LGBT, phenomenon, solution.

\begin{abstract}
Abstrak
Fenomena lesbian, gay, biseksual dan transgender (LGBT) pada zaman milenial ini bukan lagi dianggap sebagai hal yang baru di tengah masyarakat. Dahulu perilaku-perilaku tersebut dianggap prilak $u$ yang sangat tabu bagi sebagian orang, akan tetapi di zaman teknologi yang semakin canggih, hal tersebut sudah menjadi hal yang biasa. Hari ini banyak yang sudah secara terbuka menyatakan dan mengidentifikasikan dirinya sebagai identitas kaum LGBT atau sebagai pendukung terhadap perkembangannya. Gelombang besar kelompok ini berusaha keras untuk diakui di mata dunia telah dilakukan secara gencar dan terus menerus. Indonesia sebagai muslim terbesar tidak terlepas dari pengaruh dan ancaman LGBT. Penelitian ini bertujuan untuk menggali bagaimana fenomena perkembangan LGBT dan menggambarkan bagaimana solusi dan upaya untuk pencegahannya. Penelitian ini disusun dengan menggunakan pendekatan kajian literatur yang berhubungan dengan kajian LGBT. Hasil dari penggalian tersebut didapatkan bahwa pergerakan LGBT bukan lagi sekedar pergerakan individu akan tetapi telah masuk ke ranah public. Untuk mengatasi kondisi ini, disamping adanya regulasi terkait pergerakan kaum LGBT, di lingkungan terkecil dalam rumah tangga harus mempersiapkan metode dan cara dalam menangkal kehadiran LGBT.
\end{abstract}

Kata Kunci: LGBT, Fenomena, Pencegaban.

\section{Latar Belakang}

Fenomena lesbian, gay, biseksual dan transgender atau yang disingkat dengan LGBT pada hari ini bukan merupakan hal yang baru dalam masyarakat. Jika dahulu perilaku-perilaku tersebut dianggap tabu bagi sebagian orang, kini pada zaman teknologi semakin canggih, menjadi tidak tabu lagi. Banyak orang yang mengaku bahwa dirinya termasuk kaum homoseksual sudah secara terbuka menyatakan dan mengidentifikasikan dirinya sebagai identitas kaum LGBT. Gelombang besar 
kelompok LGBT yang berusaha keras untuk diakui di mata dunia telah dilakukan secara gencar dan terus menerus hingga saat ini. ${ }^{1}$

Perilaku penyimpangan seks seperti LGBT menurut beberapa sumber mememperlihatkan kecenderungan terus meningkat jumlahnya di Indonesia. LGBT merupakan istilah yang digunakan sejak tahun 1990-an untuk menggantikan frasa "komunitas gay". Meskipun awalnya, komunitas LGBT muncul dan tumbuh kembang di negara-negara maju (Barat) namun secara perlahan tapi pasti, komunitas ini pun bermunculan di negara-negara berkembang, seperti Indonesia. Sehingga keberadaan komunitas LGBT menjadi fenomena dan sebuah fakta sosial. Kehadiran komunitas LGBT tak ayal menjadi lahan perdebatan di tengah- tengah masyarakat Indonesia pada saat ini. Timbul kalangan yang pro dan kontra terhadap LGBT. Bagi yang setuju dengan keberadaan LGBT mengharapkan keberadaannya di hargai atas dasar kemanusiaan, bukan lagi dipandang sebagai perilaku kelainan mental, dan memiliki akses politik, ekonomi, dan di semua bidang lainnya yang sama dengan kalangan heteroseksual. Bagi yang kontra dengan LGBT, memandang perilaku ini menyimpang, berdosa, menimbulkan kerusakan tatanan sosial kemanusiaan hingga mengarah kepada terjadinya kepunahan spesies manusia. LGBT juga dipandang sebagai kelainan mental dan memerlukan terapi dampingan untuk menyembuhkannya.

Bahkan menurut kelompok kontra kehadiran komunitas LGBT ini akan menyebabkan sanksi Tuhan kepada bangsa yang membiarkan prilaku ini terjadi di tengahtengah masyarakatnya. Hal ini diperkuat dengan temuan Ulrike Boehmer dan Ronit

1 Ani Khairani and Didin Saefudin, 'Homoseksual Berdasarkan Pandangan Psikologi Islam', Ta'dibuna: Jurnal Pendidikan Islam, 2018 <https://doi.org/10.32832/tadibuna.v7i2.1356>.
Elk, keduanya merupakan pegiat kesehatan di Amerika Serikat bahwa penyakit kvanker banyak ditemukan di komunitas LGBT di Amerika Serikat. ${ }^{2}$ Namun terlepas dari pro dan kontra terhadap LGBT, ada satu hal yang tidak bisa ditolak bahwa isu ini sudah menjadi fakta sosial yang terjadi di tengah masyarakat. Sehingga fenomena ini tidak cukup hanya dibahas dalam tataran pro dan kontra, tapi harus dilakukan upaya penanganan dan pencegahan.

Di Indonesia sendiri memang belum ada data statistik pasti tentang jumlah LGBT, buka dan dengan mudah mengakui orientasinya ${ }^{3}$ Perkembangan LGBT tersebut juga diiringai dengan semakin banyaknya organisasi-organisasi terkait komunitas tersebut. Gerakan yang mendorong penerimaan keberadaan mereka juga semakin gencar di kampanyekan di dunia. Saat ini beberapa kaum homoseksual sudah tidak malu untuk membuka diri kepada masyarakat. Telah cukup banyak perkumpulan organisasi homoseksual terbentuk dan berkembang khususnya di Indonesia. Legalisasi homoseksual di negara-negara barat menjadi rujukan bagi mereka untuk terus aktif dalam mewujudkan keinginan mereka untuk melegalisasikan homoseks di Indonesia.

Berbagai bentuk upaya mengenalkan dan mencitrakan bahwa LGBT tersebut sesuatu yang lazim di masyarakat terus dilakukan. Melalui media massa baik elektronik maupun cetak memberitakan legalisasi LGBT di berbagai Negara di dunia. Melalui berbagai film, sinetron dan acara-acara televisi juga kita sering temui gaya hidup LGBT seolah dicitrakan seperti sesuatu yang normal dan biasa saja. Seolah berbagai tayangan tersebut mendorong anak-anak muda untuk meniru gaya hidup LGBT.

2 Abdul Malik (UIN Raden Intan Malik) Gazali, 'Fenomena Lgbt Dalam Perspektif Ham Dan Doktrin Agama (Solusi Dan Pencegahan)', Refleksi, 2017.

3 Ayu M, (2009) m Edisi 2. Jakarta: EGC. 2009. 
Bukti bahwa aktivis LGBT bergerak secara massive adalah kejadian di tahun lalu, terdengar isu bahwa ada rencana regulasi terhadap kasus LGBT di Indonesia. Ketua MPR Zulkifli Hasan mengatakan bahwa terdapat lima fraksi di DPR yang ingin melakukan regulasi tersebut. ${ }^{4}$ Disisi lain Jusuf Kalla menegaskan bahwa legalitas LGBT tidak akan diberikan di negara ini. Walaupun Jusuf Kalla sendiri mengiyakan bahwa LBGT merupakan fakta sosial yang ada di masyarakat namun tidak perlu dibawa hingga ke ranah legalisasi

Fakta di atas menampilkan isu mengenai fenomena LGBT yang merupakan focus penelitan ini. Secara lebih rinci pertanyaan penelitiannya adalah bagaimana fenomena LGBT yang berkembang di Indonesia hari ini serta bagaiamana solusi dan upaya dalam membentengi masyarakat dari penularan perilaku menyimpang tersebut.

\section{Metodologi Penelitian}

Penelitian yang dilakukan adalah jenis penelitian kepustakaan (library research). Penelitian kepustakaan merupakan penelitian kualitatif yang secara umum bertujuan untuk memahami (understanding) makna yang disimbolkan dalam perilaku masyarakat menurut perspektif masyarakat itu sendiri. ${ }^{5}$ (Literatur review) Merupakan penelitian yang mengkaji atau meninjau secara kritis pengetahuan, gagasan, atau temuan yang terdapat dalam tubuh literature berorientasi akademik (academic oriented literature), serta merumuskan kontribusi teoritis dan metodologisnya untuk topic tertentu.

${ }^{4}$ Antara. (2018, Januari 23). Kalla: LGBT Tidak Akan Legal di Indonesia. Retrieved Maret 19, 2018, from Mediaindonesia.com:

http://mediaindonesia.com/read/detail/142012-kallalgbttidak-akan-legal-di-indonesia

5 Imam Suprayogo dan Thobroni, Metodologi Penelitian Sosial-Agama, (Bandung: Rosda, 2001) Cet. I, hal. 8 .
Sumber primer yang dijadikan bahan pada penelitian ini adalah ayat- ayat al-Qur'an dan hadits-hadits Nabi SAW yang sahih yang terdapat dalam kitab-kitab hadits otoritatif, terkait masalah LGBT. Sedangkan sumber skunder adalah setiap karya atau tulisan para tokoh yang terkait pembahasan pada penelitian ini, baik klasik maupun kontemporer. Content analisys dilakukan pada penjelasan-penjelasan yang dilakukan oleh para ulama/cendekia terhadap pemahaman mereka mengenai LGBT.

Analisi isi digunakan untuk memperoleh informasi dan keterangan sekaligus pemahaman pada teks yang dilakukan oleh para ulama/tokoh. Karena dengan analisis isi dapat dicapai kesimpulan pemahaman terhadap suatu naskah. Selain itu untuk mengungkap fenomena LGBT perlu dilakukan pendekatan fenomologis. Pendekatan fenomologis dapat mengungkap esensi dari maraknya komunitas LGBT yang terjadi di masyarakat. ${ }^{6}$ Di samping itu juga dilakukan aspek psikologis dalam memahami kejiwaan individu-individu LGBT yang berada di tengah masyarakat. ${ }^{7}$ Dilengkapi dengan pendekatan sejarah, terutama dalam mengkaji kisah kaum Nabi Luth yang terangkum dalam al-Qur'an, asbab wurud al-hadits. Pendekatan sejarah dirasa tepat untuk mengetahui latar belakang, lingkungan, budaya sosial dan politik pada kelompok masyarakat tertentu. ${ }^{8}$ Dari sini dapat dilihat pengaruh yang terjadi terhadap kecenderungan dan pemikiran seseorang maupun komunitas. Sebab, menurut Shiddiqi, karakter yang menonjol dari pendekatan sejarah adalah tentang signifikansi waktu dan prinsip-prinsip

${ }^{6}$ Peter Connolly, Aneka Pendekatan Studi Agama terjemahan dari Approaches to the Study of Religion, (Yogyakarta: LKIS, 2002), cet. I, hal. 105

7 Lihat, Peter Connolly, Aneka Pendekatan Studi Agama, hal.189

${ }^{8}$ Abuddin Nata, Metodologi Studi Islam, Jakarta : Raja Grafindo, 2008) Edisi Revisi-12, hal. 46-48. 
kesejarahan tentang individualitas dan perkembangan.

\section{Fenomena LGBT}

Dalam kajian Abdurrahman al-Jaziri, homoseksual adalah perbuatan kriminal moral yang tidak layak dengan spesies manusia, dan firah penciptaannya yang Allah tetapkan. Homoseksual akan mengancam kepunahan spesies manusia dan keluar dari tabi'at natural manusia. Sehingga Al-Qur'an menyebutnya sebagai 'fahisyah' sama seperti zina. Maka hukumannya seperti pezina. Hanya saja perbedaannya adalah pelakunya dihukum mati, jika sudah menikah, sedangkan korbannya cukup dicambuk saja. Tapi ada yang berpendapat semuanya dihukum mati. ${ }^{9}$ Menurut Dadang Hawari, seorang psikolog, prilaku seksual terdiri dari beberapa jenis. Pertama, prilaku psikoseksual normatif yaitu hubungan seksual di antara pria dan wanita dewasa melalui pernikahan. Kedua, prilaku psikoseksual non normatif yaitu hubungan seksual antara pria dan wanita dewasa di luar pernikahan atau disebut juga sebagai perzinaan. Misalnya prilaku seks bebas, hidup bersama tanpa nikah (samen leven), perselingkuhan dan pelacuran. Ketiga, Disfungsi seksual adalah libido yang menurun akibat proses penuaan (menopause) dan akibat faktor-faktor psikologis. Misalnya impotensi dan frigiditas. Keempat, penyimpangan perilaku seksual yang terdiri dari transeksualisme, gangguan identitas jenis pada masa kanak-kanak, zoofilia, pedofilia, transvestisme, eksibionisme, fetishisme, voyeurisme, masokisme seksual, pelecehan seksual (incest), sadisme seksual, kekerasan seksual (perkosaan) dan homoseksualitas ${ }^{10}$.

\footnotetext{
${ }_{9}$ Aburrahman al-Jaziri, al-Fiqh "ala Madzabib alArba'ah, (Kairo : ar Rayyan, th) hal.112

10 Dadang Hawari, Al-Qur'an:Ilmu Kedokteran Jiwa dan Kesehatan Jiwa (Jakarta:Dana Bhakti Prima Yasa, 2004-), h. 677-732; Rita Subagio, Homoseksual (LGBT)
}

Keberadaan LGBT di Indonesia masih menjadi kontroversi di negara yang mayoritas muslim serta menjunjung nilai moral yang tinggi. Homoseksual yang pada awalnya dianggap tabu dan menakutkan oleh sebagian besar kalangan masyarakat. Namun saat ini tak sedikit masyarakat Indonesia yang telah menerima kehadiran mereka sebagai salah satu dari keragaman, bukan lagi suatu hal yang menyimpang. Tak kurang dari 1\% penduduk Indonesia adalah pelaku seks menyimpang (gay dan lesbian), jumlah itu akan terus bertambah sejalan dengan perkembangan dan eksistensi asosiasi homoseksual di Indonesia. ${ }^{11}$

Homoseksual merupakan masalah global dan modern sekarang ini, gaya hidup atau life style merupakan hal yang sangat penting dan kerap menjadi ajang untuk menunjukkan identitas diri. Homoseksual sudah menjadi suatu fenomena yang banyak dibicarakan di dalam masyarakat, baik di berbagai negara maupun di Indonesia. Di Indonesia sendiri homoseksual masih menjadi suatu fenomena seksual yang tidak lazim dan dianggap aneh oleh sebagian masyarakat.

Di negara-negara barat fenomena LGBT sudah tidak lagi menjadi suatu fenomena yang dianggap tabu lagi. ${ }^{12}$ Orientasi seksual yang lazim ada dalam masyarakat adalah heteroseksual sedangkan homoseksual oleh masyarakat dianggap sebagai penyimpangan orientasi seksual. Orientasi seksual disebabkan oleh interaksi yang kompleks antara faktor lingkungan, kognitif, dan biologis. Pada sebagian besar individu, orientasi seksual terbentuk sejak masa kecil.

dan Problem Psikologi Sekuler, Jurnal Islamia, INSIST,Jakarta, hal. 14.

.${ }^{11}$ Siyoto, Sandu dan Dhita Kurnia Sari. Analisa Faktor-Faktor yang Berbubungan Dengan Perilaku Homoseksual (Gay) di Kota Kediri Di Jurnal Strada Volume 3, No. 12014

12 Soetjiningsih, Tumbuh Kembang Remaja dan Permasalahannya, Jakarta: CV. Sagung Seto, 2004 
Hasil penelitian sebelumnya menunjukkan bahwa ada kombinasi antara faktor biologis dan lingkungan sebagai penyebab orientasi seksual homoseksual. ${ }^{13}$ Laki Laki yang homoseks disebut Gay, sedangkan perempuan yang homoseks disebut lesbian. Homoseksualitas mengacu pada interaksi seksual dan atau romantis antara pribadi yang berjenis kelamin sama secara situasional atau berkelanjutan. Seorang gay mengacu pada salah satu atau lebih dari karakteristik yaitu same-sex feeling (memiliki ketertarikan sesama jenis), same-sexbehaviour (pernah berhubungan seks dengan sesama jenis), dan mengidentifiikasi dirinya sendiri sebagai gay. ${ }^{14}$

Ada banyak pendapat dimana teori queer ini dibedakan dari teori pembebasan gay yang paling awal. Dengan munculnya seksualitas di era modern seseorang ditempatkan dalam kategori tertentu yaitu kedua pasangan tidak bertindak atas kecenderungan baik yang aktif maupun pasif. Maka dari itu pemahaman seksualitas tidak dapat ditinjau dari segi natural semua pemahaman seksualitas dibangun dan dimediasi oleh pemahaman budaya. Akibatnya kaum homoseksual gay ataupun lesbian pada saat ini menganggap diri mereka itu normal dikarenakan mereka menganggap apa yang terjadi pada diri mereka merupakan perkembangan sosial semata. ${ }^{15}$

\section{Faktor-faktor yang berhubungan dengan penyebaran LGBT}

Secara umum, terjadinya perilaku LGBT dipicu oleh dua hal, yaitu factor syahwat (hormon seksualitas) dan

13 Kartono, K. Psikologi Abnormal dan Abnormalitas Seksual, Bandung: Mandar Maju, 2005.

14 Siyoto, Sandu, and Dhita Kurnia Sari. "Analisis Faktor-Faktor Yang Berhubungan

Dengan Perilaku Homoseksual (Gay) Di Kota Kediri. Di Jurnal Strada Volume 3, No. 12014

15 Kartono, Psikologi Abnormal dan Abnormalitas Seksual, Bandung: Mandar Maju, 2005. pembenaran akal (pemikiran). Secara biologis, tubuh manusia memiliki sistem hormonal yang salah satunya berhubungan dengan dorongan nafsu seksualitas dan orientasi seksualnya. Penguatan rangsangan yang masuk melalui inderawi (mata, telinga, kulit) dapat memicu aktivitas hormonal tubuh yang mendorong aksi pemenuhan kebutuhan biologis berupa penyaluran seksualitas. Seseorang yang melihat, mendengar, tersentuh sesuatu terkait seks, baik tayangan pornografi, mendengar aktivitas seks atau sentuhan kulit akibat aktivitas seksualitas akan mendorong rangsangan seks. Seseorang akan memiliki hasrat penyaluran seksualitas ketika ada pemicunya tersebut.

Jika selama ini yang diketahuinya bahwa penyaluran seksualitas sesuai aturan agama, seperti hanya pada pasangan heteroseksual, setelah menikah, ditempat yang dibolehkan dan seterusnya maka perilaku seksualitasnya akan mengarah kepada penyaluran yang lazim tersebut. Namun sebaliknya jika yang dipikirkannya atau orientasi seksualitasnya terjadi sebaliknya maka yang muncul adalah penyimpangan seperti Lesbian, Gay, Biseksual, dan transgender (LGBT). Penyimpangan tersebut dapat terjadi karena pengetahuan seks yang diperolehnya mengarah kepada perilaku LGBT baik secara langsung maupun tidak.

Di sisi lain dorongan pemikiran yang menganggap perilaku LGBT (seks non heteroseksual) sebagai hal yang lazim akan mengarahkan penyaluran hasrat seksualitas dari aktivitas hormonal tubuh tersebut turut menyimpang sesuai kemauan arahan pikiran. Selain faktor hormonal, kebanyakan faktor lingkungan mempengaruhi seseorang untuk menjadi gay. ${ }^{16} \quad$ Lingkungan secara langsung

16 Siyoto, Sandu, and Dhita Kurnia Sari. Analisis Faktor-Faktor Yang Berhubungan Dengan Perilaku Homoseksual (Gay) Di Kota Kediri. Jurnal Strada 3.1 (2014). 
maupun tidak langsung dapat mengajarkan dan membentuk pemikiran pada diri manusia bahwa sesuatu yang tadinya tabu atau tidak lazim menjadi dianggap lazim. Logika pemikiran seseorang menjadi berubah yang sebelumnya tidak menganggap LGBT sebagai hal yang lazim menjadi menganggap sesuatu yang lazim.

Pembenaran perilaku LGBT juga dapat terjadi melalui peristiwa kehidupan yang dialaminya. Lingkungan yang tidak diharapkan juga dapat memicu pelarian kepada perilaku yang penyimpang sebagai ekspresi penolakan. Seseorang dapat menjadi homoseksual dikarenakan keluarga yang tidak harmonis, misalnya figur bapak sebagai lakilaki yang kejam membuat seseorang dapat menjadi homoseksual serta faktor lingkungan (konstruksi sosial) sangat mempengaruhi perkembangan seorang anak, termasuk pembentukan atau pemilihan orientasi seksualnya. Bagaimana interaksi orang tua mengasuh anak, hubungan antar keluarga, lingkungan pergaulan dan pertemanan, semuanya dapat menjadi perantara penyebaran LGBT

Pemicu penyimpangan orientasi seks tersebut juga dapat terjadi karena adanya interaksi beberapa faktor sekaligus, meliputi faktor lingkungan (sosiokultural), biologis, dan faktor pribadi/personal (psikologis). Kenyataan ini menunjukkan bahwa pertemanan menuju perbuatan dan permainan seksual sebenarnya merupakan hal yang tidak wajar. Kematangan seksual tidak selalu sejajar dengan pertambahan usia. Jika pada tahun 1980-an, perilaku homoseksual itu masih masuk pada perilaku penyimpangan seksual. Namun dari tahun 2000, homoseksual telah masuk pada gaya hidup (lifestyle).
Beberapa faktor yang berhubungan dengan perilaku LGBT antara lain: ${ }^{17}$

1. Psikologi

Pengalaman hubungan orang tua dan anak sangat berpengaruh pada kecenderungan homoseksual (gay/lesbian) atau LGBT. Umumnya pelaku gay merasa bahwa orang tuanya dahulu memberikan pengalaman yang diingat oleh mereka sampai saat ini. Dalam cara berpakain dan berdandan secara psikologis dapat menimbulkan berperilaku homoseksual (gay/lesbian). Permainan yang dimainkan mereka di massa kanakkanak sangat berpengaruh dengan perilaku homoseksual (gay/lesbian). Para pelaku lesbian tidak menyukai hal-hal yang berhubungan dengan permainan laki-laki dan teman-teman mereka pun di masa kecil banyak yang perempuan sampai dengan saat ini, dan hal sebaliknya terjadi pada pelaku gay.

Ada pula pelaku gay atau lesbian di masa lalu mendapat pengalaman yang kurang menyenangkan dari heteroseksual ataupun keluarga sendiri yang akhirnya menjadikan mereka trauma kecewa dan menjadi gay/lesbian. Beberapa hasil penelitian juga menyebutkan patah hati yang dialaminya juga menjadikan penyebab kecenderungan menjadi gay/lesbian.

2. Pola Asuh Orang Tua

Para pelaku LGBT menyebutkan bahwa pola asuh orang tua berdampak pada perilaku menyimpang yang dia alami. Contohnya pola asuh orang tua yang sangat memanjakan sehingga mereka merasa yang paling diperhatikan dan dituruti semua keinginannya. Penyimpangan pola asuh juga dapat terjadi

17 Yudiyanto, 'Fenomena Lesbian, Gay, Biseksual Dan Transgender (LGBT) Di Indonesia Serta Upaya Pencegahannya', Nizham Journal of Islamic Studies, 5.1 (2016), 63-74. 
seperti karena mempunyai 'hubungan yang buruk dengan ibu tirinya.

Rasa benci timbul dengan perempuan dan mengganggap perempuan itu selalu kejam, sehingga pelaku gay menjadi nyaman dengan laki-laki sampai dengan saat ini. Pola asuh orang tua yang keliru seperti karena keinginan mempunyai anak perempuan atau laki-laki sehingga mendorong penerapan pola asuh sesuai harapan tersebut. Terhadap anak perempuan terlalu maskulin dan sebaliknya.

\section{Pengalaman Seksual}

Seksual/Pelecehan Seksual)

Beberapa hasil penelitian menyebutkan bahwa timbulnya perilaku penyimpangan yang dilakukan oleh pelaku gay atau lesbian dikarenakan pernah mendapat pengalaman seksual yang kurang menyenangkan dari lingkungan bahkan di dalam keluarga mereka sendiri. Baik dilakukan oleh yang sesama jenis atau bahkan yang heteroseksual. Bentuk pelecehan seksual yang dialami oleh mereka relatif beragam. Contohnya perlakuan dipaksa dan dipegangi alat kelaminnya. Ada pula yang pengalaman seksual yang dialami seperti mengoral kelamin kakak kandungnya sendiri dan ada juga alat kelamin seseorang yang menjadi panutan di ponpes digesek gesekkan di alat kelamin mereka dan lainlain.

\section{Pornografi}

Maraknya penyebaran pornografi di berbagai media cetak, tayangan televisi dan internet memicu keinginan anak atau seseorang untuk mencoba atau menirunya. Berbagai tulisan, gambar dan aksi pronografi terpapar di mana-mana. Di majalah, korang, buku-buku, komix, media social, televise dan internet. Semua mengirimkan pesan bahwa perilaku LGBT seolah menyenangkan, suatu perbuatan yang biasa saja, hingga dimaknai suatu kelaziman. Apalagi semua bentuk pornografi tersebut dilihat oleh anak-anak dan remaja. Maka sesuai karakter di usia mereka sebagai peniru yang ulung, maka keinginan untuk meniru dan mencoba praktik LGBT akan mudah terjadi.

\section{Narkoba}

Penyebaran perilaku LGBT
juga sangat mudah terjadi pada
komunitas pengguna narkotika dan
obat-obatan terlarang. Dalam kondisi
yang tidak sadar karena pengaruh narkoba
mereka dapat mengalami pelecehan seksual
dan melakukan penyimpangan seks kapan
saja. Ketergantungan akan narkoba
tersebut juga menjerat mereka untuk
mudah dipaksa untuk melakukan praktik
LGBT.

\section{Rentanitas Anak dan Remaja Terhadap Perilaku LGBT}

Adanya kecenderungan timbulnya permasalahan penyimpangan perilaku seks dapat terjadi di saat usia anak dan remaja. Hal ini sesuai dengan karakter anak dan remaja yang masih mudah terpengaruh oleh lingkungan sekitarnya. Berdasarkan beberapa penelitian sebelumnya, penyimpangan perilkau seks atau dis-orientasi seks tersebut terjadi akibat kelainan yang bersifat psikologis atau kejiwaan. Seorang individu anak tidak akan tahu tentang praktik perilaku LGBT jika tidak dicontohkan atau dikenalkan oleh orang lain.

Maka awal perilaku penyimpangan tersebut dapat melalui faktor lingkungan pergaulannya, juga dapat terjadi akibat faktor genetik atau keturunan, dan dapat pula terjadi karena keinginan individu itu sendiri untuk mencoba sesuatu yang baru yang belum pernah mereka rasakan. Hasil 
penelitian yang dilakukan oleh Jamingat dan Anggraeni tentang perilaku dan gaya hidup komunitas gay dengan melakukan studi kasus di Pasar Seni Kelurahan Enggal Bandar Lampung pada tahun 2013 menunjukkan bahwa gay adalah suatu penyakit kejiwaan yang sebagian orang menganggapnya sesuatu yang sangat tabu. Namun realita di tengah masyarakat di perkotaan berbeda dengan pendapat tersebut. Di perkotaan cukup sering ditemukan adanya pasangan gay. Hasil penelitian tersebut juga menyebutkan bahwa gay akan berperilaku terbuka hanya terhadap teman terdekat dan pasangannya saja. Perilaku terbuka terhadap teman terdekatnya yang juga sesama gay hanya untuk sekedar saling mencurahkan apa yang mereka alami pada pasangannya ataupun hanya sekedar mencari pasangan baru.

Sedangkan perilaku tertutup gay pada masyarakat luas disebabkan karena privasi. Sebagian besar para gay bergaya hidup glamour. Gaya hidup yang glamour pada suatu komunitas gay biasanya sebagian besar hanya berpura-pura terlihat glamour dan mewah di komunitasnya hanya karena alasan gengsi. Ada sebagian yang keadaan ekonominya benar-benar menunjang untuk bergaya hidup glamour dan mewah, dan ada pula sebagian gay yang keadaan ekonominya sangat lah tidak dapat menunjang untuk bergaya hidup glamour. ${ }^{18}$

Beberapa dampak negatif yang sering ditimbulkan oleh perilaku LGBT antara lain :

1. Kesehatan; perilaku seks homo dan lesbian lebih beresiko terjangkit virus HIV/AIDS dan penyakit kelamin yang sulit terobati. sekitar 78\% pelaku homo seksual terjangkit penyakit kelamin menular. ${ }^{19}$

18 Jamingat, Susan Wira Anggraeni, "Perilaku Dan Gaya Hidup Komunitas Gay (Studi di Pasar Seni Kelurahan Enggal, Bandar Lampung." 2013.

${ }^{19}$ Hartono, Aput. Faktor Risiko Kejadian Penyakit Menular Seksual (Pms) Pada Komunitas Gay Mitra Strategis Perkumpulan Keluarga Berencana Indonesia (Pkbi)
Selain penyakit kelamin, LGBT juga menimbulkan penyakit AIDS yang belum diketahui obatnya. Kecenderungan rata-rata umur kaum gay dan lesbian relatif lebih pendek.

2. Moralitas; LGBT menciderai kemanusiaan kita. Pelaku homo dan lesbian telah mengingkari ALLAH yang telah menciptakan manusia berpasangpasangan sebagai fitrahnya.

3. Sosial; perilaku gay dan lesbian tidak akan bisa menghasilkan keturunan, kerusakan keluarga dan menghancurkan nasab. Jika perilaku tersebut dilegalkan maka di masa yang akan datang akan terjadi kepunahan spesies manusia.

4. Keamanan; dalam komunitas LGBT sering terjadi tindak kekerasan seksual dan pembunuhan. Hal ini terjadi karena pelaku LGBT yang mudah berganti pasangan, kecenderungan pemaksaan kehendak dominan terhadap pasangan sejenis, kesenangan yang membabibuta, atau sebaliknya kekecewaan berat yang berujung pembunuhan terhadap pasangan sejenisnya. Dalam praktik pemenuhan hasrat seksualnya tidak jarang mereka juga menempuh kekerasan terhadap anakanak, dan kaum wanita lemah lainnya yang diinginkannya.

\section{Pandangan Islam terhadap LGBT}

Dalam ajaran agama Islam perilaku LGBT dipandang sebagai perilaku seksual yang menyimpang dan merupakan dosa besar, $\mathrm{Al}$ Qur"an jelas menerangkan bahwa perilaku LGBT merupakan penyimpangan seks yang telah ada sejak zaman dahulu. Dalam AlQuran surat al A'raf 80-81:

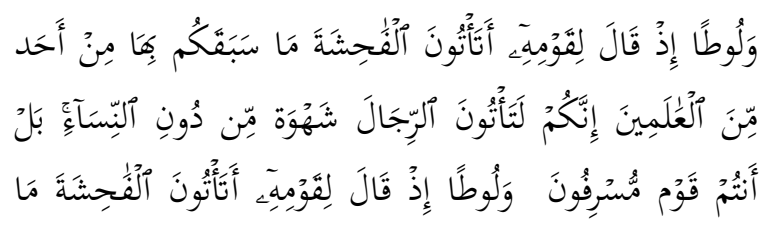

Yogyakarta. Diss. Universitas Muhammadiyah Surakarta, 2009. 


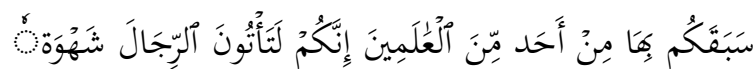

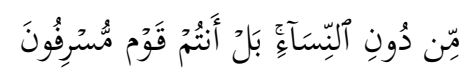

"Dan (kami juga telah mengutus) Luth (kepada kaumnya). (Ingatlah) tatkala Dia berkata kepada mereka: "Mengapa kamu mengerjakan perbuatan faabisyah (keji) itu, yang belum pernah dikerjakan oleb seorang pun (di dunia ini) sebelummu?' Sesunggubnya kamu mendatangi lelaki untuk. melepaskan nafsumu (kepada mereka), bukan kepada wanita, babkan kamu adalah kaum yang melampuai batas" (QS. Al-A'raf ayat 80-81)

Dari Ibnu Abbas Radhiyallahu 'anbuma, Rasulullah Shallallabu 'alaibi wa sallam bersabda,

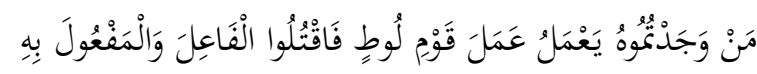
"Siapa menjumpai orang yang melakukan perbuatan homo seperti kelakuan kaum Luth maka bunublab pelaku dan objeknya!" (HR. Ahmad 2784, Abu Daud 4462, dan disahihkan al-Albani).

Ayat Al Quran dan Hadist di atas menjelaskan bahwa praktek homoseks merupakan satu dosa besar dan sangat berat sanksinya di dunia. Apabila tidak dikenakan di dunia maka sanksi tersebut akan diberlakukan di akhirat. Hukuman bagi pelaku sibaq (lesbi), menurut kesepakatan para ulama, adalah ta"zir, yang artinya pihak pemerintah yang memiliki wewenang untuk menentukan hukuman yang paling tepat, sehingga bisa memberikan efek jera bagi pelaku perbuatan haram tersebut.

Imam Syaukani menegaskan bahwa Tidak ada sanksi yang paling tepat untuk pelaku homoseksual melainkan sanksi yang dapat menjadi pelajaran bagi orang lain, dan sanksi fisik yang dapat mengekang syahwat para pelaku yang keras kepala. Bahkan Sayyiq Sabiq menukil pendapat kedokteran terkait efek negatif dari perbuatan homo seksual. Menurutnya pula, meskipun para ulama sepakat mengkategorikan homoseksual sebagai dosa besar dan tindakan kriminal, namun mereka berbeda pendapat tentang hukuman bagi pelaku homoseksual pada garis besarnya terbagi menjadi tiga kelompok. ${ }^{20}$

1. Hukuman pelaku Homoseksual adalah mutlak dihukum mati. Ini pendapat para sahabat Nabi SAW, seperti Abu Bakar, Umar, Usman dan Ali, dan telah mereka terapkan pada masa kekhilafahan mereka. Begitu pula diikuti oleh Nashir, Qasim bin Ibrahim, dan Imam Syafi'i. Mereka berpendapat bahwa hukuman pelaku homoseksual adalah hukum mati baik pelaku maupun pasangannya, baik perawan maupun sudah menikah.

2. Kelompok kedua berpendapat, hukuman pelaku homoseksual adalah cambuk dan pengasingan (tagrīb) bagi lajang dan rajam bagi yang sudah menikah, seperti hukuman pezina. Pendapat ini dipegang oleh Sa'id bin Musayyab, Atho bin Abu Ribah, Hasan al-Basri, Qatadah, an-Nakh'I, Tsauri, Awza'I, Abu Thalib, Yahya bin Ma'in, Syafi'I dalam satu perkataannya.

3. Kelompok ketiga, berpendapat bahwa pelaku homoseksual cukup dihukum peringatan keras (ta'zir), dalam bentuk kurungan (pengasingan) maupun pencambukan sesuai keputusan hakim. Ini pendapat Abu Hanifah, al- Muayyid billah, al-Murtadha dan Syafi'I dalam satu perkataan. Dengan dalih perbuatan homosesksual bukan zina maka tidak dapat diterapkan hukumannya. Imam Syaukani mentarjih (memenangkan) pendapat hukuman mati dan menolak pendapat ketiga karena bertentangan dengan dalil yang sharīh.

Dalam kajian Abdurrahman al-Jaziri, homoseksual adalah perbuatan kriminal moral yang tidak layak dengan spesies manusia, dan fitrah penciptaannya yang Allah tetapkan. Homoseksual akan

${ }^{20}$ Sayid Sabiq, Figh Sunnah, 2/434. 
mengancam kepunahan spesies manusia dan keluar dari tabi'at natural manusia. Sehingga Al-Qur'an menyebutnya sebagai 'fahisyah' sama seperti zina. Maka hukumannya seperti pezina. Hanya saja perbedaannya adalah pelakunya dihukum mati, jika sudah menikah, sedangkan korbannya cukup dicambuk saja. Tapi ada yang berpendapat semuanya dihukum mati. ${ }^{21}$

\section{Solusi dan Upaya Pencegahan LGBT}

Secara ideal, Islam dan juga agamaagama lain, selalu hadir dalam gagasangagasan besar tentang kemanusiaan: Humanisme Universal (insaniyyah). Agama memang dihadirkan tuhan untuk sebuah pembebasan terhadap seluruh bentuk penindasan, tirani, kebiadaban, dan perbudakan manusia. Bahkan penulis bisa katakan bahwa awal pintu masuk kenabian adalah revolusi mental, bukan hukum. Inilah yang disebut dengan "imajinatif kenabian.,"22

Secara historis, fenomena LGBT dapat ditemukan dalam sejarah peradaban umat manusia, khususnya merujuk kepada kisah-kisah kaumnya Nabi Luth yang dijelaskan langsung oleh Al-Qur'an. Islam secara terang mengecam tindakan yang tidak wajar tersebut. Tak hanya itu, bahkan pelaku sodom harus rela dibinasakan dari permukaan bumi ini (Qs.Al-'Ankabut, 29:31-32), sebab mereka tidak hanya merugikan dirinya sendiri, tetapi juga memberikan dampak sosial yang buruk terhadap lingkunganya. Memang pro dan kontra Ulama Tafsir dalam memahami ayat ini pun muncul ke permukaan, sejumlah pertanyaan misalnya, jika memang LGBT adalah murni problem kejiwaan atau alamiyah, mengapa Tuhan mengadzab mereka? Ada juga yang berpendapat liberal dan radikal dengan pendekatan "analisis Historis" yang

${ }^{21}$ Abdurrahman al-Jaziri, al-Fiqh 'ala Madzahib al-Arba'ah, (Kairo: ar Rayyan, tth.)5.hal.112

22 Gazali. menyatakan, kita tidak tahu cerita itu historis atau ahistoris, yang jelas Allah ingin memberikan pesan-pesan moral universalnya agar tak merugikan diri sendiri dan orang lain. Hemat peneliti, faktor yang paling penting mengapa mereka diadzab adalah dampak sosial yang buruk, alias problem kejiwaan sekaligus sosial. Bahkan LGBT seperti sudah menjadi sebuah gerakan masif.

Kalau merujuk kepada Al-Qur'an, setidaknya ada dua ayat yang menunjukkan bahwa manusia mempunyai tugas reproduksi. Pertama, Qs. An- nisa': (1). Kedua, Qs. Arrum, (21). Dari kedua ayat di atas menunjukkan bahwa Fungsi reproduksi kemanusiaan ini sudah mutlak dalam diri setiap individu. Jika ada orang menikah, lalu tidak mengharapkan memiliki keturunan, apakah ini kodrati? Tentu saja jawabannya tidak. Dan juga dari awalnya saja Allah sudah menurunkan wawaddah dan rahmah dalam konteks sosial hubungan pria dan wanita. Dengan sudut pandang demikian, bagaimanapun manusia sudah berusaha meletakkan sesuatu secara proposional hingga dapat memberikan kesimpulan bahwa Lesbian, gay, biseksual, dan transgender (LGBT) berarti menyalahi kodrat kemanusiaan universal. Dan jalan keluar untuk pemecahan masalah ini harus dilakukan dengan cara dialogis, konsultatif, dan terlebih penting lagi secara bertahap.

Beberapa peristiwa tindak penyimpangan orientasi seksual dilakukan oleh kalangan LGBT melalui praktik pornografi dan adopsi anak. Mereka menyebarkan perilaku LGBT tersebut melalui media internet sehingga diharapkan menjadi sesuatu yang lazim dan legal di tengah masyarakat. Semakin banyaknya pornografi penyebaran LGBT tersebut jika tidak dicegah akan menimbulkan efek penyebaran LGBT yang cepat. Melalui kamuflase adopsi anak, para 
pelaku LGBT juga leluasa mempraktikkan perilaku LGBT.

Untuk mencegah hal tersebut, negara telah menetapkan pencegahan penyimpangan orientasi seksual dan menjelaskannya dalam Undang-undang No. 44 tahun 2008 tentang pornografi dan telah memasukkan istilah "persenggamaan yang menyimpang" sebagai salah satu unsur pornografi. Dalam penjelasan pengertian istilah ini mencakup antara lain persenggamaan atau aktivitas seksual lainnya dengan mayat, binatang, oral seks, anal seks, lesbian, dan homoseksual.

Dalam pencegahan penyimpangan LGBT melalui praktik adopsi anak, negara juga telah mengantisipasi motif perbuatan tersebut melalui Peraturan Pemerintah No. 54 tahun 2007 tentang Adopsi yang secara secara tegas menetapkan bahwa orang tua yang mengadopsi tidak boleh pasangan homoseksual. Demikian pula adopsi oleh orang yang belum menikah tidak diperkenankan. Namun meskipun upaya pencegahan secara formal telah dilakukan oleh Negara, namun penyebaran LGBT akan tetap dapat terjadi jika diri dan lingkungan terdekat termasuk keluarga menjadi pintu penyebaran LGBT.

\section{Peran Keluarga dan Pendidikan seks bagi Anak}

Di era keterbukaan media dan teknologi informasi dewasa ini ruang untuk terpapar berbagai konten negatif seperti pornografi, LGBT dan penyimpanganpenyimpangan moral lainnnya akan semakin besar. Dalam lingkup pendidikan anak, selain dampak positif kemajuan teknologi informasi untuk belajar dan mengakses pengetahuan lebih luas dan cepat, peluang mengakses konten negative tersebut juga besar. Oleh karena itu diperlukan strategi tersendiri untuk mengantifipasi pengaruh negatif teknologi informasi terutama terkait dengan penyebaran LGBT.

Sebagai manusia, karakter positif dan negatif, potensi menjadi baik dan buruk telah ada pada setiap individu. Masing-masing sifat tersebut dapat berkembang dan terbentuk dari pengaruh internal diri maupun lingkungannya. Pada anak-anak dan remaja, pengaruh lingkungan sangat besar dalam membentuk karakter dirinya. Lingkungan keluarga, sekolah, teman bermain dan masyarakat sekitar menjadi penting untuk diperhatikan serta dikelola agar menciptakan kondisi lingkungan yang baik bagi tumbuh kembang anak dan remaja. Dalam upaya pencegahan penularan perilaku LGBT, ketahanan keluarga, keharmonisan di tengah keluarga, pola asuh yang tepat, dan pemberian pendidikan yang baik menjadi penting. Selain itu pengajaran dari orang tua dan lingkungan terdekat akan bagaimana pendidikan seks untuk menumbuhkan rasa tanggungjawab diri atas nilai seks biologis, gender dan orientasi gender menjadi penting untuk diberikan kepada anak dan remaja.

Islam telah mengatur bagaimana mengajarkan tentang seks dan gender sehingga menumbuhkan rasa tanggung jawab anak sejak dini untuk kehormatan diri dan kemanusiaannya. Anak-anak dan remaja membutuhkan pendidikan seksual yang mengajarkan betapa berharganya tubuh dan cara menjaganya. Pola pendidikan seksual dalam Islam yang relatif praktis dapat berikan oleh orang tua kepada anaknya tidaklah melalui metode pembahasan lisan yang menghilangkan rasa malu manusia. Metode pendidikan kenabian tersebut sejalan dengan fitrah manusia yang malu membicarakan hal-hal yang seronok, karena dapat berdampak menggusur secara bertahap kepekaan terhadap nilai- nilai akhlak yang luhur. Hal ini berbeda dengan metode barat yang penuh dengan muatan seronok dalam pendidikan seksual. Karena rangsangan 
seksual itu tidak memerlukan pembicaraan, Namun timbul karena terlihatnya bagianbagian yang merangsang dari lawan jenisnya. Karena itulah Islam melakukan pencegahan sedini mungkin agar rangsangan yang bersifat naluriah itu tidak mengakibatkan bahaya bagi anak-anak. Cara-cara pengajaran pendidikan seksual Islami yang diajarkan Rasulullah SAW antara lain:

\section{Pemisahan Tempat Tidur}

Rasulullah SAW bersabda :

"Surublab anak-anakmu shalat ketika mereka berumur tujuh tabun, dan pukullah mereka (tanpa menyakitkan jika tidak. mau shalat) ketika mereka berumur sepuluh tabun; dan pisabkanlah tempat tidur mereka." (HR. Abu Dawud)

Pada usia sekitar 10 tahun, umumnya anak-anak telah mempunyai kesanggupan untuk menyadari perbedaan kelamin. Maka sesuai hadist tersebut dianjurkan untuk melakukan pemisahan tempat tidur. Hal ini secara praktis membangkitkan kesadaran pada anak-anak tentang status perbedaan kelamin. Cara semacam ini di samping memelihara nilai akhlaq sekaligus mendidik anak mengetahui batas pergaulan antara laki-laki dan perempuan. ${ }^{23}$

2. Pelarangan dua orang laki tidur bersama dalam satu kamar dalam keadaan tidak berbusana

Hal ini akan menjadi pintu masuk terjadinya penyimpangan orientasi seksual yang biasanya diawali dengan keingintahuan. Begitu juga larangan ini berlaku untuk kaum perempuan. Diriwayatkan dari Samurah bin Jundub bahwa Rasulullah SAW melarang wanita tidur bersama tanpa busana, begitupun

${ }^{23}$ Yudiyanto. laki-laki dengan laki-laki lain tanpa busana. Hadis riwayat Imam Thabrani. ${ }^{24}$

3. Pelarangan dua lelaki maupun wanita bersentuhan badannya dalam kondisi tidak berbusana.

Hal itu juga akan menimbulkan orientasi penyimpangan seksual. Sebagaimana yang diungkap dalam beberapa hadits yang diriwayatkan dari Abdullah bin Abbas bahwa Nabi SAW melarang seorang laki-laki bersentuhan tubuhnya (tanpa busana) dengan laki-laki lain, begitu pula wanita dengan wanita lainnya. Tidak hanya melarang tubuh bersentuhan, upaya pencegahan juga dilakukan dengan larangan seorang laki-laki melihat aurat laki-laki lain begitupun wanita dilarangan melihat aurat wanita yang lain. Diriwayatkan oleh Abu Sa'id al-Khudri bahwa Rasulullah SAW bersabda:'Janganlah seorang lakilaki melihat aurat laki-laki yang lain, begitu juga seorang wanita melihat aurat wanita yang lain. Dan janganlah dua lakilaki berkumpul dalam satu pakaian (sehingga melihat aurat masing-masing), begitupun dua wanita berkumpul dalam satu pakaian. Hadits ini diriwayatkan oleh Imam Muslim dengan sanad sahih. ${ }^{25}$ Maksud hadits ini larangan mempertontonkan aurat laki-laki dihadapan laki-laki lain begitu pun wanita tidak diperkenankan mempertontonkan auratnya di hadapan wanita lain. Hadits-hadits di atas berisikan upaya-upaya pencegahan agar tidak terjadi penyimpangan orientasi seksual.
24 Gazali.

${ }^{25}$ Muslim bin Hajjaj an-Nisaburi, Shahih Muslim, 
4. Menanamkan Rasa Malu Pada Anak

Rasa malu harus ditanamkan kepada anak sejak dini. Jangan biasakan anak-anak, walau masih kecil, bertelanjang di depan orang lain; misalnya ketika keluar kamar mandi, berganti pakaian, dan sebagainya. Terkadang orang tua atau orang dewasa di sekitar anak-anak memberikan respon yang kurang tepat dalam menanamkan rasa malu. Contohnya ketika anak-anak keluar dari kamar mandi bertelanjang tanpa kita sadari respon orang dewasa disekitarnya justru menertawakan kelucuan tersebut. Hal ini tanpa sadar justru akan dimaknai oleh anak-anak bahwa tidak menutup aurat sebagai sesuatu yang baik dan menyenangkan orang banyak.

5. Menanamkan Jiwa Maskulinitas dan Feminitas

Orang tua perlu selalu memberikan pakaian yang sesuai dengan jenis kelamin anak, sehingga mereka terbiasa untuk berperilaku sesuai dengan fitrahnya. Anak-anak juga harus selalu diperlakukan sesuai dengan jenis kelaminnya. Hal ini sesuai aturan islam bahwa Ibnu Abbas ra. berkata: Rasulullah SAW melaknat lakilaki yang berperilaku menyerupai wanita dan wanita yang berperilaku penyerupai laki-laki. (HR al- Bukhari).

6. Penguatan pendidikan agama dalam keluarga.

Pendekatan pendidikan agama dapat memunculkan kekuatan imun dari perilaku menyimpang. Untuk lebih jauh upaya pencegahan ini diharapkan para orang tua maupun masyarakat mengawasi penggunaan teknologi internet, terkait konten- konten perilaku penyimpangan. Itu beberapa langkah pencegahan yang perlu dilakukan agar tidak terjadi penyimpangan orientasi seksual.
Adapun peranan orang tua terhadap pendidikan seks yang Islami bagi anak-anak menurut pemikiran Abdullah Nashih Ulwan terbagi dalam dua aspek, yaitu internal (ke dalam) dan eksternal (ke luar). Tanggung jawab pendidikan seks secara internal antara lain:

1. Mengajarkan etika meminta izin masuk rumah

2. Mengajarkan etika memandang

3. Menjauhkan anak-anak dari rangsangan seksual dengan upaya preventif, yaitu pengawasan baik kedalam (internal) maupun keluar (eksternal).

4. Mengajarkan hukum agama pada anak usia puber dan akhil baligh

5. Menjelaskan seluk beluk seks kepada anak.

Selanjutnya beberapa bentuk tanggung jawab dari para orang tua secara eksternal antara lain:

1. Mencegah kerusakan akibat fenomena kejahatan di masyarakat

2. Memilihkan teman bergaul yang baik

3. Pengawasan terhadap pengaruh pergaulan yang berlainan jenis

4. Memilihkan sekolah yang baik .

5. Bekerjasama dengan media informai, LSM (Lembaga Sosial Masyarakat), dan sebagainya. $^{26}$

Pada dasarnya homoseksual adalah penyimpangan orientasi seksual, dan dikategorikan sebagai gangguan psikologis. Menurut Dadang Hawari, perbuatan homoseksual bukanlah bawaan lahir, tapi kehadirannya pada seseorang melalui proses persinggungan dengan berbagai faktor, baik internal maupun eksternal. Menurutnya, orientasi homoseksual dapat disembuhkan

26 Yuniarti, Nurrina. Pendidikan Seks yang Islami bagi Anak-anak (Kajian atas Pemikiran Abdullah Nashih Ulwan). Diss. UIN Sunan Kalijaga, 2008. 
dengan terapi yang bersifat psikologisreligius. $^{27}$

Oleh karena itu, menurut Adian Husaini, ada beberapa langkah solusi dalam menangani wabah LGBT di Indonesia, khususnya, adalah sebagai berikut: ${ }^{28}$

1. Dalam jangka pendek, perlu dilakukan peninjauan kembali peraturan perundangundangan yang memberikan kebebasan melakukan praktik hubugan seksual sejenis. Perlu ada perbaikan dalam pasal 292 KUHP, misalnya, agar pasal itu juga mencakup perbuatan hubungan seksual sejenis dengan orang yang sama-sama dewasa. Pemerintah dan DPR perlu segera menyepakati untuk mencegah menularnya legalisasi LGBT itu dari Amerika Serikat maupun negara-negara lain, dengan cara memperketat peraturan perundang-undangan. Bisa juga sebagian warga masyarakat Indonesia yang sadar dan peduli untuk mengajukan gugatan judicial review terhadap pasal-pasal KUHP yang memberikan jalan terjadinya tindak kejahatan di bidang seksual.

2. Dalam jangka pendek pula, sebaiknya ada perguruan tinggi yang secara resmi mendirikan pusat kajian dan penanggulangan LGBT. Pusat Kajian ini bersifat komprehensif dan integratif serta lintas bidang studi. Aktivitasnya adalah melakukan penelitian-penelitian serta konsultasi psikologi dan pengobatan bagi pengidap LGBT.

3. Dalam jangka pendek pula, sebaiknya juga masjid-masjid besar membuka klinik LGBT, yang memberikan bimbingan dan penyuluhan keagamaan kepada penderita LGBT, baik secara langsung maupun melalui media online, bahkan juga pengobatan-pengobatan terhadap

27 Dadang Hawari, Pendekatan Psikoreligi pada Homoselesual, (Jakarta: Balai Penerbit FK- UI, 2009) hal. 71.

28 Adian Husaini, LGBT di Indonesia, Jakarta: INSIST, 2015), hal 114-115. penderita LGBT. Bisa dipadukan dengan terapi modern dengan beberapa bentuk pengobatan seperti bekam, ruqyah syar'iyah dan sebagainya.

4. Pemerintah bersama masyarakat perlu segera melakukan kampanye besarbesaran untuk memberikan penyuluhan tentang bahaya LGBT-termasuk membatasi kampanye-kampanye hitam pihak yang memberikan dukungan kepada legalisasi LGBT.

5. Kaum muslimin, khususnya, perlu memberikan pendekatan yang integral dalam memandang kedudukan LGBT di tengah masyarakat. Bagaimana pun pelaku LGBT adalah bagian dari umat manusia yang harus diberikan hak-haknya sesuai prinsip kemanusiaan, sambil terusmenerus disadarkan akan kekeliruan tindakan mereka. Dalam hal ini, perlu segera dilakukan pendidikan khusus untuk mencetak tenaga-tenaga da'i bidang LGBT. Lebih baik lagi jika program ini diintegrasikan dalam satu prodi di Perguruan Tinggi dalam bentuk konsentrasi program studi.

6. Para pemimpin dan tokoh-tokoh umat Islam perlu banyak melakukan pendekatan ke para pemimpin di media massa, khususnya media televisi, agar mencegah dijadikannya media massa sebagai ajang kampanye bebas penyebaran paham dan praktik LGBT ini. Karena sejujurnya merebaknya kasus LGBT keranah publik tidak bisa lepas dari peran mass media baik cetak maupun elektronik. $^{29}$

7. Secara individual, setiap muslim, harus aktif menyuarakan kebenaran, melakukan amar makruf dan nahi munkar kepada siapapun yang terindikasi ikut melakukan

29 Amran Hassan dan Salleh Amat, Kefahaman Terhadap Aspek Pendefinisian dan Ciri Utama Golongan Homoseksual, E-Bangi, Jurnal of Social Sciences and Humanities, Faculty of Social Sciences and Humanities, Universiti Kebangsaan Malaysia, Vol. 10, No. 2, 2015, hal.16-28. 
penyebaran faham legalisasi LGBT. Sebagaimana tuntunan al-Qur'an, dakwah perlu dilakukan dengan hikmah, manidzah hasanah, dan berdebat dengan cara yang lebih baik.

8. Lembaga-lembaga donor dan orang kaya di kalangan muslim perlu memberikan beasiswa secara khusus kepada calon-calon doktor yang bersedia menulis disertasi dan bersungguhsungguh untuk menekuni serta terjun dalam arena dakwah khusus penyadaran pengidap LGBT.

9. Media-media massa muslim perlu menampilkan sebanyak mungkin kisahkisah pertobatan orang-orang LGBT dan mengajak mereka untuk aktif menyuarakan pendapat mereka, agar masyarakat semakin optimis, bahwa penyakit LGBT bisa disembuhkan.

10. Orang-orang yang sadar dari LGBT perlu didukung dengan sarana dan prasarana yang memadai--khususnya oleh pemerintah agar mereka dapat berhimpun dan memberdayakan dirinya dalam menjalani aktivitas kehidupan sehari-hari dan melaksanakan aktifitas penyadaran kepada para LGBT yang belum sadar akan kekeliruannya.

\section{Kesimpulan}

Fenomena LGBT telah menjadi masalah global termasuk di Indonesia. Pertumbuhan jumlah pelaku LGBT terus meningkat setiap tahunnya. Cara penyebaran perilaku LGBT mudah terjadi karena pada setiap diri manusia memiliki unsur syahwat (hormon seksualitas) dan unsur akal pemikiran. Secara biologis manusia memiliki hormonal yang berhubungan dengan dorongan nafsu seksualitas dan orientasi seksualnya. Penguatan rangsangan yang masuk melalui inderawi (mata, telinga, kulit) dapat memicu aktivitas hormonal tubuh yang mendorong aksi pemenuhan kebutuhan biologis berupa penyaluran seksualitas.
Disisi lain dorongan pemikiran yang menganggap perilaku LGBT (seks non heteroseksual) sebagai hal yang lazim akan mengarahkan penyaluran hasrat seksualitas dari aktivitas hormonal tubuh tersebut sehingga turut menyimpang sesuai kemauan arahan pikiranya. Usia anak dan remaja merupakan masa yang paling rentan untuk tertular perilaku LGBT.

Selain pencegahan secara formal di ranah Negara baik di pusat maupun daerah seperti dengan UU pronografi, UU pernikahan, PP tentang Adopsi, perdaperda terkait penanggulangan penyakit sosial di masyarakat dan lain-lain, penguatan peran keluarga sebagai lingkungan terdekat dan lembaga sekolah diharapkan mampu mencegah LGBT. Prilaku LGBT, merupakan suatu penyakit kejiwaan yang dapat disembuhkan dan juga dapat dicegah. Penyembuhan dan pencegahan perilaku LGBT hanya dapat dilakukan secara bersama, dari tataran keluarga, masyarakat dan pemerintah, secara bersinergi. Dalam upaya pengobatan dan pencegahan perilaku LGBT, penguatan pendidikan agama dan norma-norma masyarakat perlu dihidupkan kembali. Karena doktrin agama mengikat individu dan masyarakat dalam berhubungan dengan Tuhan. Agama merupakan kekuatan yang tiada tanding untuk membentengi pribadi dari perilaku menyimpang. Melalui pendidikan seks yang islami di lingkungan keluarga sesuai dengan fitrah kemanusiaan diharapkan dapat menjadi solusi cara mencegah penyebaran perilaku LGBT di Indonesia.

\section{Daftar Kepustakaan \\ Buku Teks}

Al-Jaziri, Abdurrahman, al-Fiqh 'ala Madzahib al-Arba'ah, Kairo: ar Rayyan, th.

Aput, Hartono Faktor Risiko Kejadian Penyakit Menular Seksual (Pms) Pada Komunitas 
Gay Mitra Strategis Perkumpulan Keluarga Berencana Indonesia (Pkbi) Yogyakarta. Diss. Universitas Muhammadiyah Surakarta, 2009.

Connolly, Peter. Aneka Pendekatan Studi Agama terjemahan dari Approaches to the Study of Religion, Yogyakarta: LKIS, 2002, cet. I

Hawari, Dadang. Pendekatan Psikoreligi pada Homoseksual, Jakarta: Balai Penerbit FK- UI, 2009

Husaini, Adian. LGBT di Indonesia, Jakarta: INSIST, 2015

Kartono, K. Psikologi Abnormal dan Abnormalitas Seksual, Bandung: Mandar Maju, 2005.

M, Ayu Memahami Kesehatan Reproduksi Wanita Edisi 2. Jakarta: EGC. 2009

Nata, Abuddin, Metodologi Studi Islam, (Jakarta : Raja Grafindo, 2008) Edisi Revisi-12

Sabiq, Sayid. Fiqh Sunnah, 2 Beirut : Daar alFikr, th

Soetjiningsih, Tumbub Kembang Remaja dan Permasalahannya, Jakarta: CV. Sagung Seto, 2004

Suprayogo, Imam dan Thobroni, Metodologi Penelitian Sosial-Agama, Bandung : Rosda, 2001 Cet. I

\section{Jurnal Ilmiah}

Abdul Malik, Gazali 'Fenomena Lgbt Dalam Perspektif Ham Dan Doktrin Agama (Solusi Dan Pencegahan)', Refleksi, 2017.

Amran Hassan dan Salleh Amat, Kefahaman Terbadap Aspek Pendefinisian dan Ciri Utama Golongan Homoseksual, EBangi, Jurnal of Social Sciences and Humanities, Faculty of Social Sciences and Humanities, Universiti Kebangsaan Malaysia, Vol. 10, No. 2, 2015,Yuniarti, Nurrina. Pendidikan Seks yang Islami bagi Anak-anak (Kajian atas Pemikiran

Abdullah Nashih Ulwan). Diss. UIN Sunan Kalijaga, 2008Puteri, Hesi Eka, Kontribusi BPRS Merealisasi Financial Inclusion dalam Penguatan Ekonomi Lokal: Evaluasi Empiris dan Penguatan Strategi, Islam Realitas: Journal of Islamic \& Social Studies, Vol. 8, No. 1, Juni 2015, h. 20.
Rita Subagio, Homoseksual (LGBT) dan Problem Psikologi Sekuler, Jurnal Islamia, INSIST,-Jakarta

Siyoto, Sandu dan Dhita Kurnia Sari. Analisa Faktor-Faktor yang Berbubungan Dengan Perilaku Homoseksual (Gay) di Kota Kediri Di Jurnal Strada Volume 3, No. 12014

Siyoto, Sandu, and Dhita Kurnia Sari. "Analisis Faktor-Faktor Yang Berhubungan Dengan Perilaku Homoseksual (Gay) Di Kota Kediri. Di Jurnal Strada Volume 3, No. 12014

Yudiyanto, 'Fenomena Lesbian, Gay, Biseksual Dan Transgender (LGBT) Di Indonesia Serta Upaya Pencegahannya', Nizham Journal of Islamic Studies, 5.1 (2016), 63-74.

\section{Referensi Online}

Antara. (2018, Januari 23). Kalla: LGBT Tidak Akan Legal di Indonesia. Diakses tanggal 14 Desember 2019 http://mediaindonesia.com/read/d etail/142012-kalla-lgbttidak-akanlegal-di-indonesia 